\title{
HUMAN ORGAN DONATIONS UNDER THE "IRANIAN MODEL”: A REWARDING SCHEME FOR U.S. REGULATORY REFORM?
}

\author{
Hooman Movassagh, $\mathrm{PhD}^{*}$
}

I. INTRODUCTION

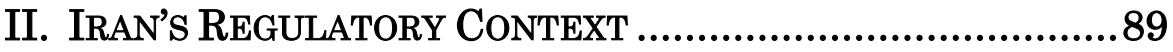

III. SHIITE APPROACHES TO HUMAN

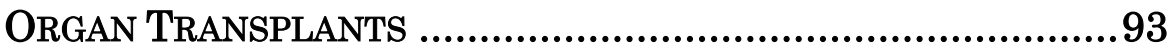

A. Transplant of Cadaveric Organs........................................... 94

B. Compensation for Human Organs ......................................... 98

IV. The Regulation and Legal Nature OF ORGaN

TRANSPLANTATION IN IRAN ............................................... 102

A. Compensated Live Organ Donations .................................... 103

B. Cadaveric Organ Transplants.................................................. 106

C. The Legal Nature of Compensated Live Organ Donation .... 109

$\mathrm{V}$. AMBIGUOUS TRANSACTIONS AND

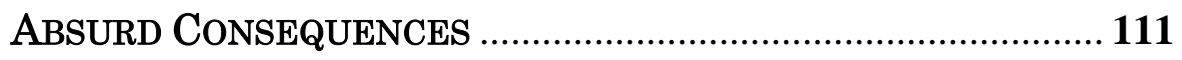

VI. CoNCLUSION ..............................................................117

* The author is a Fellow at the Institute for Practical Ethics \& Public Life at the University of Virginia. Previously, he was a lecturer at Shahid Beheshti University (SBU) Law School (2002-2012); the Director of the Bioethics Group of the Center and UNESCO Chair for Human Rights, Peace and Democracy of SBU, Tehran (2009-2012); and Visiting Professor (2013-2014) and Scholar (2012-2014) at the University of Virginia School of Law. The author thanks Dr. James F. Childress (University of Virginia) and Dr. Mohammad Rasekh (Shahid Beheshti University) for their helpful suggestions and comments on an earlier draft of this paper. He also wishes to gratefully acknowledge the input by the following UVA faculty on the substance of this paper at a colloquium at UVA School of Law: Richard J. Bonnie, Margaret F. Riley, Lois Shepherd, and Dr. Gil Siegal. Last but not least, the author wishes to thank his wife, Leili Monfared, for having patiently read and expertly commented on earlier drafts. "Needless to say, I take full responsibility for the paper as it now stands." 


\begin{abstract}
The National Organ Transplant Act has been unsuccessful in overcoming human organ shortages in the United States. There are calls for compensating human organ donations that refer to the "Iranian Model." The Iranian model is a compensated scheme for organ donations that is often mistakenly thought of as a "sale" of organs. The reality is, within the context of the Iranian legal system, the compensation is for the act of donation and is characterized as a contract of "reward." Given the specific regulations on the different forms of contract under the Iranian Civil Code, this characterization holds significant legal and ethical importance. A sale of human organs under the Civil Code would result in the immediate ownership of the organ by the purchaser, whereas this would be an absurd result under Iranian law. A proper understanding of the Iranian model is essential for potential regulatory reform in the United States. This paper sets out a precise clarification of the legal intricacies of human organ donations in Iran.
\end{abstract}

Keywords: Organ Donation, Health Policy, Medical Law, Iran, Contracts, Law and Religion, Islam.

\title{
I. INTRODUCTION
}

While transplanting human organs is currently a widely accepted practice, ethical concerns continue to exist about certain aspects of this procedure ${ }^{1}$ that affect national legal

1 Such concerns existed from the very first organ transplant, see Cornelia Dean, A Conversation with: Joseph E. Murray; On Surgical Innovation and the Questions It Can Raise, N.Y. Times (Sept. 25, 2001), http://www.nytimes.com/2001/09/25/health/conversation-with-joseph-emurray-surgical-innovation-questions-it-can-raise.html [http://perma.cc/ HD3Y-S6EP] (discussing the late Dr. Joseph E. Murray who performed the first kidney transplant in 1954 and how he was criticized for "playing God" for intending to do the transplant). The ethical aspects and concerns surrounding human organ transplants have also been echoed in international fora. See World Health Org. [WHO], Ethics, Access and Safety in Tissue and Organ Transplantation: Issues of Global Concern, at 
frameworks for human organ transplants. Of particular concern are compensated schemes for organ donations and the attendant possibility of commercialization. Although providing compensation to organ donors is currently banned in most countries and by international regulations on human organ transplants, ${ }^{2}$ there are calls by academics and activists

9, WHO/HTP/EHT/T-2003.1 (Oct. 6-9, 2003), available at http:// www.who.int/ethics/Tissue\%20and\%20Organ\%20Transplantation.pdf [http://perma.cc/7E9B-DFGF] ("[Dr Biller-Andorno] enumerated ethical concerns that can arise in the areas of deceased and living donors as well as tissue and xenotransplants. Common to all four areas are questions of eligibility and safety of donor and recipient, use of financial and other incentives, equitable access and allocation and issues of cross-border exchanges and Commercialization. She pointed out some of the major issues that need to be addressed, keeping the 1991 Guiding Principles in mind. These include on what grounds live donation can still be considered subsidiary to cadaveric donation, continuing and more complex issues of donor and recipient safety, voluntary status of consents and how best to preserve the principle of non-commercialization."); see also World Health Assembly [WHA], WHO Guiding Principles on Human Organ Transplantation, Res. WHA44.25 (May 13, 1991), available at http://www.transplant-observatory.org/SiteCollectionDocuments/

wha44resen.pdf [http://perma.cc/7EBK-U84A] (The "Guiding Principles on Human Organ Transplantation" were developed by the World Health Organization and declared on May 13, 1991, by a resolution of the World Health Assembly. The resolution contains nine Guiding Principles that are "intended to provide an orderly, ethical, and acceptable framework for regulating the acquisition and transplantation of human organs for therapeutic purposes."); see also WHO, WHO Guiding Principles on Human Cell, Tissue and Organ Transplantation [hereinafter WHO Guiding Principles], available at http://www.who.int/transplantation/ Guiding_PrinciplesTransplantation_WHA63.22en.pdf?ua=1 [http:// perma.cc/E5JZ-P52P] (developing the Guiding Principles into eleven principles that was issued in another resolution of the WHA in 2010).

2 See WHO, supra note 1; see also Additional Protocol to the Convention on Human Rights and Biomedicine Concerning Transplantation of Organs and Tissues of Human Origin, art. 21, opened for signature Jan. 24, 2002, C.E.T.S. No. 186, available at http://conventions.coe.int/Treaty/en/Treaties/Html/186.htm [http:// perma.cc/L5J4-4SFX] ("1- The human body and its parts shall not, as such, give rise to financial gain or comparable advantage. The aforementioned provision shall not prevent payments which do not constitute a financial gain or a comparable advantage, in particular: compensation of living donors for loss of earnings and any other justifiable expenses caused by the removal or by the related medical examinations; payment of a justifiable fee for legitimate medical or related technical services rendered in connection with transplantation; 
to enable some form of compensation to donors in order to overcome the organ shortage that is costing thousands of lives every year. ${ }^{3}$

In the United States, the National Organ Transplant Act of 1984 prohibits organ purchases but permits certain forms of compensation, including for lost wages and hospital costs. ${ }^{4}$ However, this and other incentives in force in the United States have proved insufficient to encourage live organ donations. Deceased donor organs fall far short of what is needed to prevent the suffering and death of thousands of people, such that 4,300 people died in the United States while on the transplant waiting list in 2013 alone. ${ }^{5}$ As a result, providing compensation to organ donors is currently being discussed as one of the means of providing sufficient incentive to live donors and to overcome the organ shortage in the United States.

A recurring reference in the discussions on compensated organ donations is Iran's organ transplant system. Iran's incentivized system of organ donations includes a scored system of transplant waiting lists for organ recipients, 6 exemption of organ donors from military service, ${ }^{7}$ and a

compensation in case of undue damage resulting from the removal of organs or tissues from living persons. 2- Advertising the need for, or availability of, organs or tissues, with a view to offering or seeking financial gain or comparable advantage, shall be prohibited.").

3 See generally SAlly SATEl, When Altruism Isn't Enough: The CASE For COMPENSATING KIDNEY DONORS (2008); SigRID FRY-REVERE, The Kidney Sellers: A JOURney OF Discovery In IRAN (2014); Sally Satel et al., State Organ-Donation Incentives Under the National Organ Transplant Act, 77 L. \& ConTEMP. PROBS. 217 (2014).

442 U.S.C. $\$ 274 \mathrm{e}(2015)$.

5 Satel et al., supra note 3, at 217.

6 For example, if a candidate for transplant is an organ donor, they are accorded four points on the waiting list, thus receiving higher priority over a non-organ donor candidate. See MASHHAD UnIV. OF MED. SCI. Transplant Procurement Unit, Protocol-e Paivand-e Kollie [Kidney TRANSPlant PROTOCOL] 23-24 (2011), available at http:// www.mums.ac.ir/shares/tmc/arghamia2/maghalat/prokidnynomosavab.p df [http://perma.cc/JWT9-XZUA]. (The original source and its translation are on file with the Indiana Health Law Review.).

${ }^{7}$ Ehda Konandegan Ozv az Sarbazi Moaf Mishavand [Organ Donors Will Be Exempt from Military Service], IRANIAN STUDENTS' NEWS AGENCY (Iran), May 20, 2013, available at http://tinyurl.com/m9wvllg [http:// 
compensated scheme of organ donations. The latter aspect of the Iranian system has been of interest in the debates on compensated organ donations, but has invariably been misunderstood as a system that authorizes the sale of organs. The payment of compensation is not synonymous with the sale and purchase of organs. The possibility of providing some form of compensation, regardless of whether or not it is done with the purpose of providing financial incentives to donors, does not necessarily mean that human organs are being bought and sold. Conflating the two has led to some ambiguities and misunderstandings about the regulated framework of organ transplants in Iran, to such an extent that the terms "kidney sellers," "organ sales" 9 and "kidney eBay" 10 have been used in describing the "Iranian model."11

This confusion is understandable, since the term "sale" is sometimes loosely used in connection with organ donations within Iran itself, particularly by laypersons. Also, the majority of Iran's population are Shiite Muslims, and many of the decrees issued by leading Shiite clerics have also used the term "sale and purchase" of organs when responding to questions on the religious aspects of organ donations. However, it must be emphasized that this is not a correct characterization. ${ }^{12}$ In fact, Iran's regulations have not used this term with respect to human organ donations, and the

perma.cc/4SXX-2DD9]. (The original source and its translation are on file with the Indiana Health Law Review.).

8 FRYE-REVERE, supra note 3.

9 Benjamin E. Hippen, Organ Sales and Moral Travails: Lessons from the Living Kidney Vendor Program in Iran, CATo Inst. (March 20, 2008), http://www.cato.org/publications/policy-analysis/organ-salesmoral-travails-lessons-living-kidney-vendor-program-iran [http:// perma.cc/ MRL8-726W].

10 Saeed Kamali Dehghan, Kidneys for Sale: Poor Iranians Compete to Sell Their Organs, GUARDIAN (May 27, 2012), http:// www.guardian.co.uk/world/2012/may/27/iran-legal-tradekidney?INTCMP=SRCH [http://perma.cc/N62D-MKQV].

11 This phrase has been used to describe the specific scheme of organ donations in Iran whereby certain cases may be compensated. See Hippen, supra note 9; Ahad J. Ghods \& Shekoufeh Savaj, Iranian Model of Paid and Regulated Living-Unrelated Kidney Donation, 1 CLINICAL J. AM. SOC'Y NEPHROLOGY 1136 (2006).

12 As will be seen below, the views of Shiite clerics are not uniform on this either. 
official terms used are "donation" (e'ta) and "gift" (ehda). Far from being merely pedantic, this characterization has considerable ethical and legal significance under Iran's legal system. A contract of sale is a specific type of contract in Iran's Civil Code and has a well-defined regime. If the donation is deemed a sale, one may be faced with the scene depicted by Shakespeare in the Merchant of Venice where Shylock insists on having his pound of flesh:

The pound of flesh, which I demand of him, Is dearly bought; 'tis mine and I will have it.

If you deny me, fie upon your law!

There is no force in the decrees of Venice.

I stand for judgment: answer; shall I have it? ${ }^{13}$

In the case of legal organ transplants, the life of any given "Antonio" may not necessarily be endangered quite as depicted by Shakespeare. ${ }^{14}$ However, the question whether or not human organs may be deemed to be property, or for some reason subject to purchase and ownership, may raise a host of other issues. Such issues may include the donors' consent, defining an acceptable transaction in form and substance, and the plethora of issues that arise from attributing ownership rights to human organs, such as the various legal relations between the donors, recipients, and third parties.

The fact that Iranian regulations differentiate between transplants using cadaveric organs and those provided by live donors is relevant here. With respect to organs obtained from live donors, a certain sum may be paid as a reward for

13 William Shakespeare, The Merchant of Venice act 4, sc. 1. Although Shakespeare was not addressing a question of organ donation or sale, the nature of the transaction under which donations are made may well result in such a scenario if the matter is not addressed sufficiently. It is essential that even in a compensated scheme for organ donations, safeguards be established to protect the rights and freedoms of the parties involved.

14 Id. Shylock, through his hatred of Antonio, insists that he must cut the flesh closest to Antonio's heart: "So says the bond: doth it not, noble judge? 'Nearest his heart': those are the very words." 
the "sacrifice" the donor has made, ${ }^{15}$ although the donor may decide to forego such compensation for altruistic or other reasons. However, no such compensation has been allowed in cadaveric organ transplants. Providing safeguards against ownership claims to human organs and for ensuring a donor's consent throughout a transplant procedure are extremely important. ${ }^{16}$

An incorrect portrayal of the Iranian system may result in a demand for similar systems being established elsewhere without enough attention to the safeguards inherent in the nature of the act of donation under Iranian law and the additional assurances of propriety included in relevant regulations and enforcement mechanisms. Certainly, the Iranian system itself requires further elaboration of regulations and strengthening of mechanisms and safeguards. Also needed is greater national awareness of the range of relevant ethical and legal aspects of transplants and a much necessary clarification of the transactions being conducted outside the defined legal scheme for live unrelated donations. ${ }^{17}$ However, despite the shortcomings of the Iranian system, there are legal safeguards that must be taken into account when considering the "Iranian model."

15 Known as "hediye'ye isar", literally meaning "gift of sacrifice." The term is also used in regulations concerning disability pay for certain veterans.

16 The case of Mr. Hu Jie, a migrant worker who changed his mind about undergoing a transplant in China but was nevertheless stripped of his kidney, illustrates this importance all too well. See Nicola Davison, In China, Criminals Fill the Kidney Donor Deficit, GUARDIAN (May 27, 2012, 15:00 EDT), http://www.guardian.co.uk/world/2012/may/27/chinakidney-donor-shortage-crime [http://perma.cc/35EJ-UUZF].

17 Although there are guidelines and information pamphlets on many of the websites and centers relevant to organ transplants, see, e.g., Shahid Beheshti U. Med. SCI. ORgan Procurement Unit, http:// ehda.sbmu.ac.ir/?fkeyid=\&siteid $=489 \&$ pageid $=34190 \quad$ [https://perma.cc/ WP22-DFK5] (last visited Dec. 2, 2015). There are at times incorrect portrayals of the system in popular media that may lead to further ambiguities or misunderstandings about organ donation. Furthermore, the law is ambiguous on the nature of human organs and the nonsystemic transactions conducted by the public. These ambiguities are addressed below. (The original source and its translation are on file with the Indiana Health Law Review.). 
This matter is of no small importance in view of the ethical and legal ramifications of compensated organ donations, the millions of people who stand to benefit from a healthier life, and the immense financial aspects involved. Therefore, with the purpose of disambiguation, a brief overview of the regulatory framework of the Iranian model is provided, and the legal nature of donations under that system is analyzed.

\section{IRAN'S REGULATORY CONTEXT}

Iran is an "Islamic Republic." This phrase means that while certain processes and institutions of government are republican in form and structure, according to Article 4 of the Iranian Constitution "All, civil, penal financial, economic, administrative, cultural, military, political, and other laws and regulations must be based on Islamic criteria." 18 Furthermore, by virtue of Article 170 of the Iranian Constitution, judges shall not give effect to laws or regulations that contradict Islamic criteria. ${ }^{19}$ Thus, the

18 QANUNI ASSASSI JUMHURII ISLAMAI IRAN [THE CONSTITUTION OF THE ISLAMIC REPUBLIC OF IRAN] 1358 [1980], art. 4. This article's Islamic principle "governs absolutely and generally all articles of the Constitution, as well as all other laws and regulations, and the duty to ascertain this matter devolves on the jurists of the Guardian Council." The Constitution mentions such determination is to take place by the six clergy members of the Guardian Council or "fuqaha," a term that has been incorrectly translated to "the wise persons," see, e.g., IranConstitution, http://www.servat.unibe.ch/icl/ir00000_.html [http:// perma.cc/PH3U-ZJ5W] (last visited Feb. 1, 2016), or simply "jurists," see, e.g., ISLAMIC PARLIAMENT OF IRAN, http://en.parliran.ir/ index.aspx?siteid=84\&pageid=3053 [https://perma.cc/27Q8-6QJP] (last visited Oct. 26, 2015). It must be noted that the Guardian Council consists of twelve members, six of whom are legal jurists and six who are Islamic jurists (faqih). A determination on the compatibility of laws and regulations with Islamic Shari'a is incumbent on the Islamic jurists, and ascertaining the compatibility with the Constitution rests with all twelve members of the Council.

19 QANUNi ASSASsi JUMHURII ISLAMAI IRAN [THE CONSTITUTION OF THE ISLAMIC REPUBLIC OF IRAN] 1358 [1980], art. 170. "Judges are obliged to refrain from" executing byelaws "and regulations of the government that are in conflict with the laws or the norms of Islam," or have been adopted by the Executive ultra vires. Anyone has the right to "demand 
drafters of the Iranian Constitution have posited Islamic Shari'a as the general moral theory of the entire legal system of Iran, permeating all laws and regulations, and determined by the clerical members of the Guardian Council. 20 Obviously, not all issues have been addressed in the Shari'a and modern advances in science and technology may pose a challenge to legislation on a strict reading of this provision.

Interestingly, the Iranian Constitution has used different terms concerning the relation of legislation and Shari'a. For example, Articles 4 and 94 provide that legislation has to correspond to "Islamic criteria;" a different phrase in Articles $72,85,91$ and 96 indicates that legislation must not contradict the "rules of Islam." 21 The Guardian Council has commented on this differentiation in defining its work ${ }^{22}$ and

the annulment of any such regulation from the Court of Administrative Justice."

20 By virtue of Article 12 of the constitution, the official school of Islamic Shari'a incumbent on the State has been declared to be that of the Twelver Ja'faris. QANUNI ASSASSI JUMHURII ISLAMAI IRAN [THE CONSTITUTION OF THE ISLAMIC REPUBLIC OF IRAN] 1358 [1980], art. 12. This article provides:

The official religion of Iran is Islam and the madhhab (school of law) is the Twelver Ja'farí school, and this article will remain forever unalterable. Other legal schools (madhãhib) including the Hanafi, Shãfi'í, Mãlikí, Hanbalí, and Zaydí, are accorded full respect, and their followers are free to perform their religious rites in accordance with their own figh. These schools are officially recognized by the courts in matters pertaining to religious education and training, personal status (marriage, divorce, inheritance, and wills), and any related litigation. In any region where the followers of any of these schools constitute a majority, the local regulations will be in accordance with that school within the jurisdiction of the local councils, with due observance of the rights of the adherents of other schools.

For a definition of madhhab and further resources on the subject, see ENCYCLOPEDIA OF ISLAM (P. Bearman, et al. eds., 2nd ed. 2012), available at http://referenceworks.brillonline.com/entries/encyclopaedia-of-islam2/madhhab-SIM_8798 [http://perma.cc/QVL7-PWWJ].

${ }^{21}$ QANUNI ASSASSI JUMHURII ISLAMAI IRAN [THE CONSTITUTION OF THE ISLAMIC REPUBLIC OF IRAN] 1358 [1980], arts. 4, 72, 85, 91, 94, 96.

22 See About the Guardian Council, GUARDIAN CounCIL, http:// www.shora-gc.ir/Portal/Home/ ShowPage.aspx?Object=News\&ID= 7ca3f12d-47c1-4ac5-a088-397771794abb\&LayoutID=e3152b95-620e- 
has held that the former formulation refers to the general principles of Shari'a such as justice, fairness, and human dignity, whereas the latter denotes such specific rules ${ }^{23}$ that have expressly been set forth in the Quran and the Sunnat. ${ }^{24}$ The Council believes these formulations are co-extensive and there is no contradiction between them. ${ }^{25}$ Instead, the Iranian Constitution provides a broader discretion to the Council in ascertaining that legislation "corresponds to Islamic criteria" and is more restrictive if legislation is found to "contradict specific rules of Islam." 26

This system enables the Guardian Council to take into consideration various policy issues when reviewing legislation passed by Parliament (the Majlis) and possibly to opt for an interpretation of Shari'a that would meet modern policy necessities. This is important since Islamic law may lack specific rules on issues raised by the advent of new technologies and advances in science, and such a reading provides more leeway for enacting any legislation that may be required for regulating such advances. Furthermore, the most prominent Islamic Jurists (fuqaha) hold differing views on many issues, 27 including the question of organ transplants, and these views may in certain exceptional circumstances be a source for adjudication of particular legal claims in courts of law.

4dfd-97f1-1fefd0f696b1\&CategoryID=8fac823a-5745-41b6-a9e2-

b879c74deb7b [http:// perma.cc/55t9-CX4Y] (last visited Oct. 26, 2015). (The original source and its translation are on file with the Indiana Health Law Review.).

23 See Encyclopedia of Islam, Second Edition: Ahkam, BRILlOnLINE REFERENCE WORKS, http://referenceworks.brillonline.com/entries/ encyclopaedia-of-islam-2/ahkam-SIM_0376 [http://perma.cc/WKC3Q3YG] (last visited Oct. 28, 2015).

24 Also written as "Sunna" or "Sunnah," generally meaning the practice and custom of Prophet Mohammad, which in addition to the Quran, is a source of Islamic law, see Encyclopedia of Islam, Second Edition: Sunna, BRILLONLINE REFERENCE WORKS, http:// referenceworks.brillonline.com/entries/encyclopaedia-of-islam-2/sunnaCOM_1123 [http://perma.cc/T2X2-BCJE] (last visited Oct. 28, 2015).

25 Infra note 29.

26 See About the Guardian Council supra note 22.

27 See Abdulaziz Sachedina, IsLAMIC BIOMEDICAL ETHICS: PRINCIPLES AND APPLICATIONS (2009), available at http:// course.sdu.edu.cn/ Download/20130908092939153.pdf [http://perma.cc/ V9S4-4WJG]. 
Finally, in the event that there is a difference of opinion between the Parliament and the Guardian Council on necessary policy considerations and Islamic criteria, the Constitution has established the Expediency Assembly to resolve the dispute between the two entities. ${ }^{28}$ This is to prevent a stalemate between the legislative policy requirements of everyday life as determined by Parliament and the possible inflexibility of the Guardian Council on a specific issue. ${ }^{29}$

As a result, the drafting process for legislation, and even regulation by entities other than Parliament, necessarily takes into consideration the dictates of Shari'a with regard to any given issue. This is not to say that other facets are ignored in toto. In drafting legislation, regard is also given to Iran's international obligations, policy requirements and questions of practicality, and the results of studies in various sciences relevant to the issue. However, the tenets of Shari'a and the views of the most highly regarded and most authoritative Islamic jurists of the Shiites (Maraji) will

28 The Constitution of the Islamic RePUblic of IRAN Oct. 24, 1979, art. 112. Article 112 of the Iranian Constitution reads in part: "The State Expediency Assembly will meet by the order of the Leader to decide what is most expedient whenever the Guardian Council considers a bill approved by the Islamic Parliament of Iran to be contrary to the principles of the Shari'a or the Constitution and the Parliament is unable to secure the satisfaction of the Guardian Council on the basis of national expediency. The State Expediency Assembly will also meet to consult on any issue referred to it by the Leader or related to its duties as mentioned in this Constitution."

29 In an interpretation of Article 4 of the Constitution by the Guardian Council, even the Expediency Assembly is barred from approving any legislation that contradicts Islamic criteria. Majmuahi Nazariati Shurai Nigahban [Compilation of the Opinions of the Guardian Council] Tehran 1993, Op. 4575. However, since this opinion appeared to contradict the very raison d'être of the Expediency Assembly, it was asked to elaborate its position. Letter from Expediency Assembly, Letter No. 3786/2409 (June 24, 1993). The Guardian Council responded by pointing to the differentiation between the primary and secondary rules of Shari'a and declared that the Constitutional provision on the Expediency Assembly's purview relates to that of secondary rules. Guardian Council, Op. 4872 (1993). In practice, once the Expediency Assembly approves an Act of Parliament, it is published in the Official Gazette as law and becomes binding. (The original sources and their translations are on file with the Indiana Health Law Review.). 
usually hold sway over conclusions that may be drawn from other moral theories that dominate either the international or "Western" policy deliberations. As a result, different regulatory conclusions may be reached in a setting where concepts such as autonomy, dignity, equality, liberty, and harm may have different meaning, scope, or importance in moral and policy deliberations.

\section{Shitte APPROACHES to Human ORgan TRANSPLANTS}

Notwithstanding the provisions of the Constitution for the purpose of legislation and the role of the Guardian Council, any real or legal person may seek the views of the Shiite Maraji' resulting in religious decrees (fatawa) with regard to questions of Shari'a requirements on certain issues. In turn these views may affect the regulatory process and content of any legislation or regulation on the matter. However, such decrees are not always uniform, and at least for legislative purposes in Iran, the Guardian Council will invariably be the ultimate source of authority on questions of Shari'a. Still, a review of the different fatawa will serve to provide a clearer picture of the context of the Iranian regulations on organ donation.

In the context of organ transplants, the criteria for death, donors and recipients, the possibility of compensation for donation, and even the sale and purchase of organs have been the subject of numerous decrees issued by a number of the Maraji'. A review of the said decrees shows a variety of views ranging from rejecting cadaveric organ transplants to their acceptance and a range of approaches on the many questions pertaining to each position. ${ }^{30}$ There is also a general

30 The review undertaken for this study consisted of decrees issued by fifty-two of the living and deceased Maraji. These are Grand Ayatollahs: Mirza Javad Gharavi Aliari, Abdollah Javadi-Amoli, Sayyid Abdul-Karim Mousavi Ardebili, Ali Asghar Rahimi Azad, Sayyid Ali Mohammad Dastgheib Shirazi, Mirza Yadollah Duzduzani, Mohammad Ishaq Fayyadh, Mohammad Hossein Fazlollah, Mohammad Taghi Bahjat Foomani, Ali Safi Golpaygani, Lotfollah Safi Golpaygani, Mohammad Ali Gerami, Sayyid Mohammad Ali Alavi Hosseini Gorgani, Sayyid Kazim Hussaini Haeri, Sayyid Mohammad Saeed Tabatabai Hakeem, Hossein Noori Hamedani, Sayyid Kamal Heydari, Mohammad Ebrahim Jannaati, Sayyid Mohammad Ali Moosavi Jazayeri, Qorban Ali Kaboli, Sayyid Ali 
acceptance of the possibility for the sale of organs by live donors for the purpose of transplantation, sometimes expressly restricted to cases where a life may be saved by the process. Of course, not every one of the said Maraji' has addressed every aspect of organ transplants. However, for the purposes of this paper, the decrees will be categorized on the basis of their rejection or acceptance of cadaveric transplants and the question of compensation for organs. ${ }^{31}$

\section{A. Transplant of Cadaveric Organs}

Among the Shiite religious authorities, some have considered certain cadaveric transplants contrary to Shari'a and thus have declared them wrong and prohibited. Such decrees generally emanate from a rejection of the brain death

Hoseyni Khamenei, Sayyid Abolghasem Khoei, Sayyid Ruhollah Khomeini, Hossein Vahid Khorasani, Mohammad Fazel Lankarani, Moslem Malakouti, Hossein Mazaheri (Esfahani), Sayyid Mohammad Taqi Modarresi, Mohammad Asif Mohseni, Hossein Ali Montazeri, Bashir Hussain Najafi, Muhammad Hussain Najafi, Sayyid Reza Hosseini Nassab, Mohammad Reza Nekoonam, Sayyid Mohammad Sadeq Hosayni Rohani, Yousuf Saanei, Sayyid Mohammad Shahroudi, Sayyid Mahmoud Hashemi Shahroudi, Naser Makarem Shirazi, Sayyid Mohammad Hussaini Shirazi, Sayyid Sadiq Hussaini Shirazi, Sayyid Ali Husayni Sistani, Ja'far Sobhani, Mirza Javad Tabrizi, Sayyid Yousef Madani Tabrizi, Saleh Taei, Mohammad Sadeghi Tehrani, Mojtaba Tehrani, Shamsodin Vaezi, Mohammad Yaqoobi, Asadollah Bayyat Zanjani, Sayyid Mohammad Ezodin Hosseini Zanjani. Of this group of fifty-two, twenty-three have issued decrees on the question of organ transplants. For a list of living and deceased Maraji' see Maraji'-e Taghlid-e Shiie [Shiite Maraji] http://fa.wikishia.net/view/\%D9\%85\%D8\%B1\%D8\%A7\% D8\%AC\%D8\%B9_\%D8\%AA\%D9\%82\%D9\%84\%DB\%8C\%D8\%AF_\%D8\% B4\%DB\%8C\%D8\% B9\%D9\%87 [https://perma.cc/UN6Z-8V3L] (last visited Jan. 9, 2016).

31 Decrees concerning other indirectly relevant matters shall not be addressed in their own right, but only insofar as they may shed light on the issues covered in this paper. The decrees issued by some of the Maraji' cover such questions as: xenotransplants; the cleanliness of an organ in the religious sense (tahara); whether or not there is any difference between organs of Muslims and non-Muslims; the special status of people condemned to death; the responsibility of medical professionals in conducting transplants; and whether blood money (diya) should be paid for transplants. 
criterion, ${ }^{32}$ or what the relevant Marja' considers to be the desecration of a Muslim's corpse;33 but some Maraji' clearly state that extraction of organs for the purpose of transplants is not desecration ${ }^{34}$ and even consider it to be a duty to save lives. ${ }^{35}$ In cases where the brain death criterion has been rejected, cadaveric transplants have been deemed permissible where the Islamic criteria for death are met, 36

32 Mohammad Taghi Bahjat Foomani, Jarahi, Tashrih, va Paivand [Surgery, Autopsy, and Transplantation], fatwa No. 1173, http://www.bahjat.ir/index.php/ahkam-2/esteftahat/192-2011-09-06-1013-34.html [http://perma.cc/EP3W-R2J9] (last visited Oct. 28, 2015); Hossein Vahid Khorasani, Ehdaye Ozv Dar Soorate Marge Maghzi [Organ Donation in Case of Brain Death], The OfFICE OF GRAND AYATULLAH AL-UzMa SHAYKH HUSAYN VAHID KHORASANI, http://www.wahidkhorasani.com/web/index.php?option=com_quickfaq\& view $=$ category \&cid=50\&Itemid=704\&lang $=$ fa $\quad[\mathrm{http}: / /$ perma.cc $]$ (last visited Oct. 30, 2015); Sayyid Ali Husayni Sistani, Ministry OF HEAlTH \& MED. EDUC., http://www.behdasht.gov.ir/ index.aspx?siteid= 1\&pageid=13186\&newsview $=4767$ [http://perma.cc/ QBM6-KM7E] (last visited Nov. 1, 2015); Ministry OF Health \& Med. Educ., http://www.behdasht.gov.ir/ index.aspx?siteid=1\&pageid=13186\& newsview $=4763$ [perma.cc/AKT4-KZZR] (last visited Nov. 1, 2015); MINISTRY OF HEALTH \& MED. EDUC., http://www.behdasht.gov.ir/ index.aspx?siteid=1\&pageid=13186\&newsview $=4762$ [perma.cc/R9E5AZPK] (last visited Nov. 1, 2015). (The original sources and their translation are on file with the Indiana Health Law Review.).

33 TOZIH-OL MASA'EL [CATECHISM] 574 (n.d.), available at http:// www.sistani.org/files-new/book-pdf/persian-tozih-edition32.pdf [https:// perma.cc/23JU-QE2G]. (The original source and its translation are on file with the Indiana Health Law Review.).

34 Sayyid Mohammad Sadeq Hosayni Rohani, http:// www.rohani.ir/istefta-772.htm [http://perma.cc/2JF8-PMB3] (last visited Nov. 1, 2015). (The original source and its translation are on file with the Indiana Health Law Review.).

35 Mohammad SADEghi Tehrani, Resale-Ye-ToziH-OL-Masaele Novin [CATEChism on New Problems], 450 Question 997 (3rd ed. 2005), available at http://forghan.org/images/book/pdf/Resale\%20NOVIN.pdf [https://perma.cc/G9CV-G93V]. (The original source and its translation are on file with the Indiana Health Law Review.).

36 Sayyid Mahmoud Hashemi Shahroudi, Marge Maghzi [Brain Death], http://hashemishahroudi.org/fa/pages/print.php?page= question\&id=629; Sayyid Mahmoud [https://perma.cc/7USV-76LR]; Hashemi Shahroudi, Pezeshki [Medicine], http://hashemishahroudi.org/ fa/pages/question.php?id=133 [https://perma.cc/XJ2U-79BK]. (The original sources and their translation are on file with the Indiana Health Law Review.). 
even in the absence of a will and testament concerning organ donation and with the sole purpose of saving a Muslim life..$^{37}$

The general contention that Muslims do not regard the definition of death as a merely scientific determination and that "the most critical issues in the determination of the time of death are essentially religious and ethical, not medical or scientific[,]" 38 is true in the majority of cases, and most of the Maraji' contend that brain death in itself is insufficient to consider a person dead. ${ }^{39}$ But a number of the Maraji' have ceded such determination to medical professionals, thereby accepting the brain death criterion, 40 and one very authoritative Marja'considers death as being defined by the "custom of experts"-that of medical professionals. ${ }^{41}$

There are also nuances among the majority on cadaveric transplants, brought about by individual appreciations of changes in socio-cultural circumstances and developments in medicine, and some have accepted transplants using organs from brain dead persons in order to save lives without addressing the criterion of death itself. ${ }^{42}$ Interestingly, one

37 Foomani, supra note 32, fatwa No. 1178-1183.

38 Sachedina supra note 26, at 145-46.

39 For instance, Sayyid Mohammad Ezodin Hosseini Zanjani references a verse of the Quran, Zumar 42, and clearly states that brain death does not constitute death in the religious sense. Nevertheless, he believes that if brain death is irreversible by any means and the brain dead person has expressed consent to donation of organs, that person's organs may be extracted and used in transplants, Shokoohe Marja'iat [Glory of Religious Authority], Montakhab-e Estefta'at-e Jadid [Selection of New Fatwas] http://azanjani.blogfa.com/8908.aspx [http://perma.cc/ 46XZ-DTCJ] (last visited Nov. 1, 2015). (The original sources and their translation are on file with the Indiana Health Law Review.).

${ }^{40}$ Mohammad Ishaq Fayyadh, AlFAYADH.ORG, http://alfayadh.org/ fa/\#post?type=post\&id=1079 [http://perma.cc/8SX6-NHMB] (last visited Nov. 1, 2015); Naser Makarem Shirazi, Ahkame Shar'i-e Mortabet ba Marg-e Maghzi [Shari'a Decrees on Brain-Death], http:// makarem.ir $/$ main.aspx?typeinfo $=21 \& l i d=0 \&$ catid $=667 \& \mathrm{mid}=9990$

[https://perma.cc/V8ZG-A6Q3] (last visited Jan. 13, 2016). (The original sources and their translation are on file with the Indiana Health Law Review.).

41 Hossein Ali Montazeri, AhKaM-E-Pezeshik [MedicAl DeCReEs] 120 (3rd ed. 2002) (question 268). (The original source and its translation are on file with the Indiana Health Law Review.).

42 Sayyid Kazim Hussaini Haeri, Alestefta'at [Requests for fatwas], http://www.alhaeri.org/main.php\#qa [http://perma.cc/ 3WY4-D8JC] 
Marja'makes a distinction between the brain death criterion for the purpose of organ transplants, and the Shari'a criteria of death for other legal or religious purposes such as power of attorney or burial. 43

According to the majority position, cadaveric transplants may take place if the life of a Muslim is dependent on the procedure. ${ }^{44}$ This approach also has a number of variations. For instance, certain Maraji' have held that if a Muslim's life is in danger, the organs of a cadaver may be used to save that person's life, even without the consent of the decedent or any other third party. ${ }^{45}$ At times, the transplant of organs has been made conditional-it must take place with the sole purpose of saving a life (or a Muslim life) and it is forbidden if it is known to be futile. ${ }^{46}$

(follow "Masa'el fi-Tashrih wa Naghl-ol-A'aza [Questions on Autopsy and Transplantation of Organs]). (The original sources and their translation are on file with the Indiana Health Law Review.).

43 Naser Makarem Shirazi, Payvande Ozve Kasi ke Marge Maghzi Shodeh [Transplanting the Organ of Someone who is Brain-Dead], http: $/ /$ makarem.ir/main.aspx?typeinfo $=21 \& l i d=0 \&$ catid $=28962 \&$ mid $=23$ 72 [https://perma.cc/77X9-KFGP] (last visited Jan. 13, 2016). (The original source and its translation are on file with the Indiana Health Law Review.).

${ }^{44}$ Haeri, supra note 42.

${ }^{45}$ Mohammad Taghi Bahjat Foomani, Pezeshki [Medicine] fatwa No. 544, http://www.bahjat.org/index.php/ahkam-2/esteftahat/105-2011-0906-09-19-55.html [http://perma.cc/3GZC-DLYG] (last visited Nov. 1, 2015). (The original sources and their translation are on file with the Indiana Health Law Review.).

46 MonTAZERI, supra note 41, at 129 (question 286); Foomani, supra note 45, fatwa No. 552, Mohammad Ishaq Fayyadh, ALFAYADH.ORG, http://alfayadh.org/fa/\#post?type=post\&id=1084 [https://perma.cc/D564UVA2]; Sayyid Mohammad Saeed Tabatabai Hakeem, http:// alhakeem.com/persian/pages/quesans/listgroup_ques.php?Where=236 [http://perma.cc/ AU2U-Q9QU] (last visited Nov. 1, 2015). The current Leader of Iran, Sayyid Ali Hoseyni Khamenei, does not differentiate between Muslims and non-Muslims, see Sayyid Ali Hoseyni Khamenei, http://nahad.sbmu.ac.ir/?siteid=269\&pageid=20612 [http://perma.cc/ A2ZD-PTMB] (last visited Nov. 1, 2015). But the former leader did make such a differentiation, see Sayyid Ruhollah Khomeini, Tashrih-o Paivand [Autopsy and Transplantation], ISLAMIC THOUGHT FouND., www.imamkhomeini.com/web1/persian/showitem.aspx?cid=915\&pid=

$2014 \& \mathrm{~h}=1 \& \mathrm{f}=2$ [http://perma.cc/2LHK-SQ74] (last visited Nov. 1, 2015). (The original sources and their translation are on file with the Indiana Health Law Review.). 


\section{B. Compensation for Human Organs}

On the question of compensation or sale and purchase of organs, the approach of the Maraji' in the past has been to ban such sale on the grounds that it was futile and would not have any reasonable benefit, because a human organ was considered to be economically worthless. ${ }^{47}$ In view of medical developments that have made organ transplants highly beneficial in saving lives and restoring good health, decrees have been issued to reflect the economic aspect of these developments and thus to enable such transactions. ${ }^{48} \mathrm{~A}$ majority of the Maraji' have clearly stated that the sale and purchase of organs is permissible, 49 while others have cautioned that the transaction should be conducted under another contractual category, such as release, assignment, gift, license, or mutual good deed (reciprocity). 50

47 See Mir Sajjad Hashemi, Asare Hoghooghie Vagozarie Ozve Ensane Morde Ya Mobtala be Marge Maghzi [Legal Consequences of Transferring the Organs of a Deceased or Brain-Dead Person], Andisheh Taghrib Periodical 50-71 (2006). (The original sources and their translation are on file with the Indiana Health Law Review.).

48 Sayyid Ali Hoseyni Khamenei, Estefta'at-e Jadid [New Questions], www.leader.ir/tree/print.php?catid=49\&nodeid=n14609

[http://perma.cc/JH9E-4LMX] (last visited Jan. 14, 2016). (The original sources and their translation are on file with the Indiana Health Law Review.).

49 This is usually with the caveat that the transplant must not be harmful to the donor. Hossein Ali Montazeri uses the "serious and irreversible harm" formula, MONTAZERI supra note 41, at 131 (question 296); Sayyid Ali Husayni Sistani only mentions "serious harm", CATECHISM, supra note 33 at 575. Some of the Maraji' have stated that while it is permissible, it is best to be abstained from, Mohammad Ebrahim Jannaati, http://www.jannaati.com/far/index.php?page=6\&row $=\quad 6 \&$ start $=36$ [http://perma.cc/GR7R-AKDU], while others have not mentioned such a restriction, Khomeini, supra note 46; Hossein Mazaheri (Esfahani), www.almazaheri.ir/farsi/Print/Print.aspx?TBlName=

PublicQuestion\&ID=484 [http://perma.cc/8QJL-L5WJ] (last visited Nov. 1, 2015); Tehrani, supra note 35, 451 fatwa No. 1000. (The original sources and their translations are on file with the Indiana Health Law Review.).

50 Mohammad Ali Gerami uses the term Raf'e yad (dispossession). See Mohammad Ali Gerami, GERAMI.ORG, www.ayat-gerami.ir/ data.asp? $\mathrm{L}=1 \& \mathrm{id}=3048$ [http://perma.cc/K33R-SEGK] (last visited Nov. 1, 2015). Sayyid Ali Hoseyni Khamenei uses the term foroosh (sell) on 
It appears that these decrees have been issued with the belief that due to developments in modern medicine, the trade of human organs may be considered rationally beneficial and hence, capable of being transferred in a sale and purchase agreement. ${ }^{51}$ However, there are decrees that restrict this position. The position that a transplant should take place only in cases where it offers hope for saving a life and is not futile also applies to the sale and purchase of organs. ${ }^{52}$

Some of the Maraji' have also declared the sale of organs by persons condemned to death to be illegal. ${ }^{53}$ However,

three occasions, see Khamenei supra note 48; Sayyid Ali Hoseyni Khamenei, $\quad \mathrm{http}: / / \mathrm{ww} w . l e a d e r . i r / t r e e / i n d e x . p h p ? c a t i d=11$ [http://perma.cc/ 8HGD-Y2EE] (last visited Nov. 1, 2015) (questions 1291 and 1518). But, in another fatwa, he specifies that organ donation may be carried out as "assignment," Khamenei, supra note 46. Naser Makarem Shirazi believes "license" is the better form of transaction, see Naser Makarem Shirazi, Paivande Tokhmdane Zan-e Ajnabi be Zojeh [Transplantation of an Unrelated Woman's Ovary to a Married Woman] http://makarem.ir/main.aspx?typeinfo $=21 \& l i d=0 \&$ catid $=28962 \&$ mid $=24$ 35 [https://perma.cc/P6H9-TK8Y]. Sayyid Mohammad Sadeq Hosayni Rohani has classified the transfer of gametes and embryos as a "gift," Sayyid Mohammad Sadeq Hosayni Rohani http://www.rohani.ir/istefta777.htm [http://perma.cc/Q936-GR8W] (last visited Nov. 1, 2015), and believes that the sale of organs or cadavers for conducting autopsies is impermissible, Sayyid Mohammad Sadeq Hosayni Rohani http://www.rohani.ir/istefta-1336.htm [http://perma.cc/U52Q-7534] (last visited Nov. 1, 2015). Yousuf Saanei believes that while the sale and purchase of organs is permissible per se, the transaction is best to be carried out under some other rubric, such as a mutual good deed. $\mathrm{He}$ believes the sale and purchase of organs may result in the belittlement of the Islamic Republic [of Iran]. See Yousuf SAANEI, EsTEFTAAT-EPeZeshik [Religious DeCREes on Medicine] 138-139 (12th ed. 2009). (The original sources and their translation are on file with the Indiana Health Law Review.).

51 Hossein Noori Hamedani, Hezar-o YeK Mas'aleh FiqHi [A THOUSAND AND ONE PROBLEMS OF FIQH], 255 (n.d.), available at http://www.noorihamedani.com/files/51d16dbcb0642.pdf

[https://perma.cc/Y5D6-P4EZ]. (The original source and its translation are on file with the Indiana Health Law Review.).

${ }^{52}$ Foomani, supra note 45, Pezeshki [Medicine] fatwa No. 506, Sayyid Mohammad Shahroudi, fatwa No. 1793, www.shahroudi.com/ Portal.aspx?pid=71243\&CaseID=34311 [http://perma.cc/E8K3-MN33] (last visited Nov. 1, 2015). (The original sources and their translation are on file with the Indiana Health Law Review.).

${ }^{53}$ Foomani, supra note 45, Pezeshki [Medicine] fatwa No. 543. 
there are decrees that provide the possibility of donating organs to benefit from a lesser punishment. For instance, Sayyid Kazim Hussaini Haeri has issued a decree stating that in cases where a person who is condemned to death is willing to donate an organ to benefit from a lesser punishment and the judge has the power and discretion to issue a lesser punishment, such donation is permissible. ${ }^{54}$ This fatwa does not address the issue of monetary compensation; rather it addresses a non-monetary incentive that seriously calls into question the autonomy of such donors.

There is also general agreement that the sale of organs does not devolve upon the heirs of a decedent by way of inheritance. Such heirs may only endorse or reject the donation of the decedent's organs, but may not receive any sums for such donation. ${ }^{55}$ This is a peculiar position and it raises the question whether the Shiite Maraji consider organs to be the property of a person.

This is a peculiar position and it raises the question whether the Shiite Maraji'consider organs to be the property of a person. If so, why do they conclude that the appertaining property rights do not pass on to a person's heirs?56 However, if human organs are not considered to be one's property, the question would arise as to the basis of the fatawa for considering the sale and purchase of organs to be permissible, since the fatawa that have been issued in allowing such sales are based on the rational benefit and worth of such organs. In fact, only two of the Maraji' have

${ }^{54}$ Haeri, supra note 42. See also MonTAZERI, supra note 41, at 130 (question 289); see also Yousuf Saanei, http://www.saanei.org/ ?view $=01,05,13,49,0$ [https://perma.cc/YGA4-43TE]. (The original sources and their translation are on file with the Indiana Health Law Review.).

${ }^{55}$ Foomani, supra note 32, Jarahi, Tashrih, va Paivand [Surgery, Autopsy, and Transplantation], fatwa No. 1171; Sayyid Kazim Hussaini Haeri also mentions that an advance directive to the effect that the decedent's organs be sold after death is void, Haeri, supra note 42. Contra Mohammad Ebrahim Jannaati, http://www.jannaati.com/far/ index.php?page $=6 \&$ row $=6 \&$ start $=42$ [http://perma.cc/ZJN6-TMH2] (last visited Nov. 1, 2015). (The original sources and their translation are on file with the Indiana Health Law Review.).

${ }^{56}$ For an exploration of the issue see Mir Sajjad Hashemi, supra note 47. 
explicitly stated that humans do not have ownership of their organs as they would of other property, ${ }^{57}$ but they may nonetheless transfer their organs in lieu of compensation. These Maraji' have not specified the form and legal qualification of such a transaction. This peculiarity is further complicated by other aspects of the positions of Maraji'that consider the sale and purchase of organs permissible. For instance, in case such a transaction is for any reason void and the donor decides to renege on the transaction, what is to become of the organ? Should it be transplanted back to the donor? Also, what would be the consequence of not include the necessary contractual safeguards for termination? If a donor were to rescind her offer to "sell" her organ, would she nonetheless be forced to undergo the transplant procedure for failing to incorporate a termination clause in the agreement?

One of the Maraji' has been asked to comment on the consequence of a void sale of a human organ and his response has been that the recipient may resell the organ to the donor. ${ }^{58}$ This is not the consequence of a void sale agreement according to Shiite fiqh and the stated position requires further clarification by the Marja'. The fact that there is no requirement for a written contract of sale in Islamic figh and that many consequences of a void sale agreement of a human organ would be left unanswered underscores the need for further thought and deliberation on the nature of human organs and the acceptable form of their transfer to others by the Maraji'that have issued fatawa on these issues.

57 Mohammad Yaqoobi, A'ttabaro' Bel A'aza [Organ Donation], http://yaqoobi.com/arabic/index.php/103/126/668.html [https://perma.cc/ YGA4-43TE ] (last visited Jan. 15, 2016); Sayyid Mahmoud Hashemi Shahroudi, Kharido Forooshe A'azaye Badan [Purchase and Sale of Organs] http://hashemishahroudi.org/fa/pages/print.php?page= question\&id=996 [https://perma.cc/HEW7-HQ3E ] (last visited Jan. 15, 2016). (The original sources and their translation are on file with the Indiana Health Law Review.).

58 Mohammad Ali Gerami, Masaeli Dar Babe Kharido Forooshe A'za [Issues on Purchase and Sale of Organs], GERAMI.ORG, www.ayatgerami.ir/data.asp?L=1\&id=3048 [http://perma.cc/7FFJ-D58S] (last visited Oct. 16, 2015). (The original sources and their translation are on file with the Indiana Health Law Review.). 


\section{The Regulation and Legal Nature of Organ TRANSPLANTATION IN IRAN}

The first kidney transplant in Iran was carried out in 1968 using the organ of a live donor and the first cadaveric transplant was performed four years later in 1972. 59 However, the first regulation on transplants was a provision in a Byelaw issued in 1976 by the Council of Ministers in respect of Article 42 (3) of the General Penal Code of 1973.60 According to Article 2 of the Byelaw, if a medical specialist determined the necessity of an organ transplant, the transplant required obtaining the written consent of the organ donor. Furthermore two other specialists had to verify that extracting the organ would not pose a foreseeable physical or mental danger to the donor. ${ }^{61}$

This provision was repeated verbatim in a corresponding article in the superseding Byelaw of $1978 .{ }^{62}$

${ }^{59}$ History of Nephrology in Iran, IRANIAN SOCIETY OF NEPHROLOGY (Dec. 2008), http://www.isn-iran.org/mainPage.php?lang=en [http:// perma.cc/496R-8AWV] (follow "Nephrology in Iran" hyperlink; then follow "History" hyperlink).

60 RUZNAMEHI RASMI KISHVARI SHAHANSHAHI IRAN [THE IMPERIAL Iranian OfFicial GaZETTE], Aiin Nameye Ejrai-e Band-e 3 Madeh-ye 42 Ghanoon-e Mojazat-e Omoomi [Implementing Byelaw on Paragraph 3 of Article 42 of the General Penal Code] Oct. 27 1976, No. 9272, available at http://dastour.ir/brows/?lid=93275 [http://perma.cc/Z5NM-XGSL]. (The original source and its translation are on file with the Indiana Health Law Review.).

61 Id. at art. 2. Article 42 (3) of the General Criminal Code provided that any surgical or medical act carried out with the consent of the rightholder and in conformity with regulations adopted and declared by the State is not a crime. GHANOON-E MOJAZAT-E OMOOMI [GENERAL PENAL CODE] Tehran 1352 [1973] (Iran), art. 42. That provision is now reinstated with minor amendments as Article 59 (2) of the Islamic Criminal Code. (The original source and its translation are on file with the Indiana Health Law Review.).

62 RuZNAMEHI RASMI JUMHURI ISLAMI IRAN [THE OFFICIAL GAZETTE OF THE ISLAMIC REPUBLIC OF IRAN], Tasvibname Darbareye Aiin Nameye Ejrai-e Band-e 3 Madeh-ye 42 Ghanoon-e Mojazat-e Omoomi [Byelaw on the Implementing Byelaw on Paragraph 3 of Article 42 of the General Penal Code] Jan. 3 1979, No. 9895 available at http:// dastour.ir/brows/?lid=\%20\%20\%20\%20\%2098292 [https://perma.cc/ 67CC-2PXD]. (The original source and its translation are on file with the Indiana Health Law Review.). 


\section{A. Compensated Live Organ Donations}

After the Islamic Revolution and almost twenty years after the aforesaid regulation, the Cabinet issued another Byelaw in 1997 simply titled "Byelaw on Kidney Donors" providing for a monetary gift to be paid to kidney donors with the intention of facilitating kidney transplants and encouraging donations. ${ }^{63}$ According to this Byelaw, the sum of ten million $(10,000,000)$ Rials shall be granted to kidney donors as reward for their good deed by the Foundation for Special Diseases."64 This is included in the national budget and paid to the Foundation by the Executive. ${ }^{65}$ Hence, although the regulation itself has been passed by the Cabinet, the monetary compensation in lieu of organ donations receives the assent of Parliament when the Budget is approved each year.

There are several interesting considerations in this provision. The Byelaw only mentions kidney transplants and has not addressed other forms of organ donations that were being carried out even then. Also, the amount is granted to the donors as a reward for their altruistic act, commonly known as the "gift of sacrifice." It is not compensation for the sale and purchase of kidneys, but for the act of donation, or "their good deed." 66 The difference between these two will be explored in more detail below, but it is important to highlight that the Iranian legal system differentiates these two

63 RUZNAMEHI RASMI JUMHURI ISLAMI IRAN [THE OFFICIAL GAZETTE OF THE ISLAMIC REPUBLIC OF IRAN], Byelaw on Kidney Donors of Feb. 25, 1997, No. 15146, available at http://dastour.ir/brows/?lid=165176 [http://perma.cc/N7D7-U6F4] (last visited Jan. 15, 2016). (The original source and its translation are on file with the Indiana Health Law Review.).

64 Id.

65 The Charity Foundation for Special Diseases was established in 1996 and is a non-governmental organization that also receives donations from private persons. CHARITY FOUNDATION FOR SPECIAL DISEASES, http://www.cffsd.org/about-us [http://perma.cc/YA9U-YKFH](last visited Oct. 16, 2015). (The original source and its translation are on file with the Indiana Health Law Review.).

66 Byelaw on Kidney Donors, supra note 63. 
transactions and the regulated scheme for compensation is not one of human organ purchase and sale.

The amount provided in the Byelaw was over forty-eight times higher than the monthly minimum wage at that time. Hence, it provided a significant financial incentive to donors, and thereby effectively overcame the kidney shortage prevalent at the time. However, this amount has remained unchanged over the years, despite the monthly minimum wage having had a twentyfold increase. ${ }^{67}$ Even if the rather conservative and cautious rates of inflation declared by the Central Bank of Iran for the past fifteen years are not factored in the equation, 68 the amount that would be commensurate with the original provision's ratio to minimum wage should be considerably higher today, standing close to two hundred and ninety four million $(293,855,140)$ Rials. The fact that no change has been made to the "Gift of Sacrifice" has caused potential donors to seek compensation elsewhere, by advertising their readiness to "sell" their kidneys to those who need one and are willing to pay the price requested by the donors.

67 See KhabarOnLine, Negahi be Hadeaghal Dastmozd Taye 34 Sale Gozashte: Faseleye Hadeaghale Dastmozd va Nerkhe Tavarom Cheghadr Ast? [A Look at the Minimum Wage over the past 34 Years: What is the Gap between the Minimum Wage and the Rate of Inflation?] www.khabaronline.ir/print/275142/economy/macroeconomics [http:// perma.cc/W7BZ-FP53] (last visited Jan. 15, 2016) (showing data published by the Central Bank of Iran that minimum wage was 207,210 Rials in 1997 and 3,900,000 Rials in 2012). Minimum wage was 608 dollars, ALEF.IR, http://alef.ir/vdcbw9b59rhb8sp.uiur.html?219589 [http://perma.cc/738C-3NYW] (last visited Oct. 16, 2015) (showing that in both 2013 and 2014 the minimum wage was again increased and now stands at just over 6,089,000 Rials). (The original sources and their translations are on file with the Indiana Health Law Review.).

68 See The Real Rate of Inflation is Above 50\%, TABNAK (Oct. 16, 2012), www.tabnak.ir/fa/print/279113 [http://perma.cc/8EJR-DLEB] (showing that the rate of inflation declared by the Central Bank of Iran (CBI) is often disputed: while average inflation for 2012-13 has been estimated at under 30 percent by the CBI, some estimates put this at over $50 \%$ or higher, going up as much as 196\%). See also Growth of $97 \%$ inflation in 20 months, ALEF.IR (Jan. 6, 2013, 11:17 AM), http://alef.ir/ vdchimnzx23nqid.tft2.html?175223 [http://perma.cc/8UBH-KPGZ] (giving an average inflation for the months of March 2011 to November 2012 estimated at 97\%). (The original source and its translation are on file with the Indiana Health Law Review.). 
The Directive on Kidney Donations and Transplants from Live Donors issued in 2008 by the Ministry of Health ${ }^{69}$ is also worthy of mention here. This Directive sets out the regulations for live donations in five sections: 1 ) the criteria for live unrelated donors; 2) medical tests and examinations prior to donation; 3) transplants for foreign nationals; 4) other provisions; and 5) monitoring. ${ }^{70}$

Section one of the Directive sets forth several factors for living unrelated donors, including age (between the age of 1845 , and over 25 for unmarried female donors), informed written consents by the donor and the donor's spouse (if married) or parents (if single), nationality, "thorough medical examinations and tests" to be carried out by specialized medical doctors which are further stipulated under section two of the Directive and detailed in relevant protocols. Furthermore, this section absolutely bars habitual intravenous drug users from donating their kidneys. ${ }^{71}$ These provisions do not stipulate a definition of "unrelated donors" or a method of verifying such status. This loophole is an oversight that is conducive to dealings whereby parties may claim to be related, thereby "selling" their organs on the market and foregoing the reward foreseen in the regulatory framework altogether, which is currently of little to no value.

In addition to the provision in section one of the Directive requiring the donor and recipient to be nationals of the same State, section three provides further provisions to ban transplants between people of different nationalities. ${ }^{72}$ This section states that transplants for non-Iranians may only

69 Dastoor-ol Amal-e Ehda va Paivand Kollieh az Ehda Konandegane Zendeh [Directive on Kidney Donations and Transplants from Live Donors] of 20 October 2008, [hereinafter Directive on Kidney Donations and Transplants from Live Donors] available at http://www.behdasht.gov.ir/index.aspx?siteid=1\&pageid=13401\&newsvi ew=5813 [https://perma.cc/ BDM9-AQDU]. The Directive was prepared through a collaborative undertaking by the following: Academy of Medical Sciences, Iranian Society of Organ Transplantation, Transplantation and Dialysis Council, Medical Ethics Research Center of Tehran University of Medical Sciences, and the Legal Department of the Ministry of Health and Medical Education. (The original source and its translation are on file with the Indiana Health Law Review.).

70 Id.

71 Id. $§ 1(5)$.

72 Id. 
take place between those who are nationals of the same State. ${ }^{73}$ The only exception is that of married couples who may have different nationalities. ${ }^{74}$ By virtue of this section, transplants for all foreign nationals requires specific written license. Furthermore, according to a separate Byelaw issued on the subject of transplants for foreign nationals, such license may only be given by the Center for Dialysis and Organ Transplants of Iran. The license must be in writing and issued upon satisfaction of the relevant criteria for transplants for foreign nationals. ${ }^{75}$

Under section four of the Directive, any organized coordination with the purpose of organ donations by Iranians in other States has been prohibited. 76 This section also prohibits any advertising or notice for donation and threatens legal action for any violations by those who place or publish a notice or advertisement for requesting an organ. ${ }^{77}$ It further prohibits any brokerage or trade in the process of kidney donations from live donors. Monitoring these regulations has been entrusted to the "experts of the Department of Transplants and Special Diseases of the Ministry of Health" and "the experts of medical sciences universities across the nation", the sanction for violations being the complete shutdown of the transplant ward. ${ }^{78}$

\section{B. Cadaveric Organ Transplants}

Separate regulations govern the transplant of cadaveric organs. Regulating cadaveric organ transplants in Iran has not been an easy task due to the religious obstacles involved. However, with the issuance of fatawa on the matter, the Parliament of Iran enacted a law on April 5, 2000 entitled:

${ }^{73} I d . \S 3(1)$

74 Id. $\$ 3(2)$

75 Vct.kmu.ac.ir, A'in Nameye Payvande Kollieye Atba'e Khareji [Organ Transplant of Foreign Nationals Byelaw], http://vct.kmu.ac.ir/ Images/UserUpload/Document/VCT/darman/aeen\%20name.pdf [https:// perma.cc/S9JX-Z4TA ] (last visited Jan. 15, 2016). (The original source and its translation are on file with the Indiana Health Law Review.).

76 Directive on Kidney Donations and Transplants from Live Donors, supra note $69, \S 4(3)$.

77 Id. $\S 4(1)$.

78 Id. $\S 5$. 
"Transplant of Organs from Deceased Patients or Patients with Evident Brain Death" (hereafter the Brain Death Law or BDL). ${ }^{79}$ The law was neither approved nor rejected by the Guardian Council and thus entered into force in accordance with Article 94 of the Constitution. ${ }^{80}$ Furthermore, a Byelaw issued on the $18^{\text {th }}$ of June 2001 was issued to complement the BDL. 81

The BDL provides that equipped hospitals may use the healthy organs of deceased patients, or patients who have been ascertained to be brain dead by experts, for transplanting to patients whose life depend on the organ(s). 82 This is subject to the deceased or brain dead patients' will and testament, or the consent of their heirs. It also requires the hospital to have obtained written authorization from the Ministry of Health for this purpose. ${ }^{83}$

Several points are noteworthy. The question of consent has been highlighted in the BDL and further elaborated in the BDL Byelaw. The donor may have declared consent orally

79 Law on the Transplant of Organs from Deceased Patients or Patients with Evident Brain Death of 5 Apr. 2000 (Iran), [hereinafter Law on the Transplant of Organs from Deceased Patients] available at dastour.ir/Print/?lid=188843 [https://perma.cc/KM2M-WMCD]. (The original source and its translation are on file with the Indiana Health Law Review.).

80 ISLAHAT VA TAQYYRATI VA TATMIMAH QANUNI ASSASSI [AMENDMENT to THE Constitution] 1368 [1989], art. 94 (Iran). Article 94 states that: "[a]ll legislation passed by the Islamic Consultative Assembly must be sent to the Guardian Council. The Guardian Council must review it within a maximum of ten days from its receipt with a view to ensuring its compatibility with the criteria of Islam and the Constitution. If it finds the legislation incompatible, it will return it to the Assembly for review. Otherwise the legislation will be deemed enforceable."

81 Implementing Byelaw for the Law on the Transplant of Organs from Deceased Patients or Patients with Evident Brain Death of 18 June 2001 [hereinafter Implementing Byelaw] available at http://dastour.ir/brows/?lid=258228 [https://perma.cc/ Z2HX-23W2] (last visited Oct. 16, 2015). See also DASTOUR.IR, http://dastour.ir/brows/?lid=260706 [https://perma.cc/SMJ4-C6QQ ] (last visited Oct. 16, 2015) (detailing a minor amendment to the BDL Byelaw that was made on 4 September 2002). (The original source and its translation are on file with the Indiana Health Law Review.).

82 Directive on Kidney Donations and Transplants from Live Donors, supra note $76, \S 5$.

83 Id. 
or in writing prior to death, or the heirs may provide consent post mortem. The heirs or "wali" is defined in the BDL Byelaw based on descent and distribution provisions of the Civil Code. ${ }^{84}$ Where the decedent donor has given consent orally prior to death, consent may be evidenced by a written declaration of a single legal heir. ${ }^{85}$ Also, if the written consent of the deceased is not readily available, any legal heir who is certain of the will of the deceased to donate may sign a declaration and testify to that effect. ${ }^{86}$

Experts who are authorized to determine brain death are appointed by the Ministry for a period of four years and stationed in equipped public university hospitals, their determination of brain death must be based on a protocol prepared by the Ministry, 87 and they cannot be members of a transplant team. ${ }^{88}$ The BDL Byelaw provides that these experts must consist of four medical doctors specializing in neurology, neurosurgery, internal medicine, and

84 See Qanuni Madani [Civil Code] Tehran 1314 [1935], art. 862 (Iran). Article 7 of the BDL Byelaw has departed from the definition of wali under Article 1180 et seq. of the Civil Code and has defined this according to the provisions on inheritance. The Byelaw defines the wali of the deceased as legally adult heirs who can consent to the organ transplant. See also id., art. 862 (defining heirs as: 1 - Father and mother and children, and grandchildren; 2 - Grandparents, brother and sister and their children; 3 - Paternal uncles and paternal aunts, maternal uncles and maternal aunts and their children). See also id. art. 864 (defining the spouse of a deceased person as an heir by cause of marriage). Cf. QANuni Mojazate Eslami [Islamic Penal Code] Tehran 1370 [1991], art. 261 available at http://dastour.ir/Print/?lid=143178 [https:// perma.cc/A224-ZRRF ] (also defining the wali as heirs of the decedent, except that the BDL Byelaw is inclusive of the spouse of the deceased and it requires the written consent of all heirs, meaning those who would be first in line as descendants for the purpose of inheritance). (The original sources and their translations are on file with the Indiana Health Law Review.).

85 Implementing Byelaw, supra note 81, art. 6.

$86 I d$.

87 See Protocol-e Taiin-e Marg-e Maghzi [Protocol on the Determination of Brain Death], ASS'N OF ORGAN DONATION SUPPORTERS, http://www.nafase-javid.ir/showthread.php?tid=71

[https://perma.cc/YL39-AKVN] (last visited Jan. 16, 2016). (The original source and its translation are on file with the Indiana Health Law Review.).

88 Law on the Transplant of Organs from Deceased Patients, supra note 79; Implementing Byelaw, supra note 81 arts. $2 \& 3$. 
anesthesiology. ${ }^{89}$ Their examination of the patient must take place independently of the others and if their determination is unanimous, an expert in legal medicine shall verify their determination. ${ }^{90}$

While the BDL does not provide a definition of brain death, Article one of the BDL Byelaw defines this as the "complete and irreversible cessation of all cortical, subcortical and brain stem activity." 91 The various tests for this determination have been set out in the protocol. This provides practical finality to the differing fatawa on the matter and establishes a legal frame of reference on the question of brain death. Furthermore, an Explanatory Note issued by the Legal Department of the Judiciary on 12 May 2008 states that brain death is synonymous with death and entails all legal consequences of death. ${ }^{92}$

Last but not least, no compensation has been allowed in the regulations for the donation of cadaveric organs. In addition to the fatawa holding that no compensation may be made for consenting to the use of cadaveric organs by the heirs of the deceased, the websites of the various transplant authorities in Iran have also mentioned this restriction. ${ }^{93}$

\section{The Legal Nature of Compensated Live Organ Donation}

The legal nature of donations under the current regulations of Iran must be assessed against the background of the more general provisions of the Iranian legal system, particularly the Civil Code. The Code, modeled after the French Code Civil and drawing upon Islamic fiqh of the Twelver persuasion, has differentiated between various kinds of contracts. Article 10 of the Code recognizes the

89 Implementing Byelaw, supra note 81, art. 2.

90 Id. arts. $2 \& 3$.

91 Implementing Byelaw, supra note 81, art. 1.

92 Opinion Number 7/1004, May 12, 2008, available at http:// dastour.ir/brows/?lid=335364. (The original source and its translation are on file with the Indiana Health Law Review.).

93 See, e.g., EHDA.IR, http://ehda.sbmu.ac.ir/?fkeyid=\&siteid= 489\&pageid=34591[https://perma.cc/3C8P-UHNQ] (last visited Jan. 17, 2016). (The original source and its translation are on file with the Indiana Health Law Review.). 
general freedom to contract, ${ }^{94}$ and rules governing the general law of contracts and obligations have been set forth in various provisions. A number of specific types of contracts have been addressed and subjected to separate rules, each type of contract having a special regime.

It has already been clarified that no compensation is due for cadaveric organs and that the Byelaw on Kidney Donors of 1997 has only established a framework for compensated live organ donation as described above. The legal nature of this undertaking is best characterized as a contract of reward ${ }^{95}$ or ju'alah, as defined by article 561 of the Civil Code as engaging a person to make a payment in exchange for an act even if the other party is not known. This provision provides the possibility of compensating any act that is not illegal or unreasonable. 96 This latter condition should be read in tandem with the general provision for the object of transactions under the Civil Code, whereby the object of a contract must be valuable and provide for a "reasonable and legitimate advantage." ${ }^{97}$ As noted previously, the transfer of organs was traditionally considered to lack a reasonable and legitimate advantage. However, with the possibility of transplanting organs to save lives and restore health, the numerous fatawa issued by the most senior Maraji, and the resultant laws and regulations on transplants, there is no question as to the reasonable advantages of such transactions or to their legality.

The contract of reward may be offered to a specific person or the general public, thereby permitting the public tender of an act such as kidney donation. Furthermore, a contract of

94 QAnuni Madani [Civil Code] Tehran 1314 [1935], art. 10. Article 10 provides that: "private contracts shall be binding on those who have signed them, providing they are not contrary to the explicit Provisions of a law." (The original source and its translation are on file with the Indiana Health Law Review.).

95 See Muhammad Ayub, Understanding Islamic Finance, 351 (2009); see also MuHAMmad Yusuf SALEem, Islamic CoMmercial LAW, 61-64 (2013) (for a general explanation of this type of contract in Islamic law).

96 QANUni Madani [CIVIL Code] Tehran 1314 [1935], art. 570 (Iran). (The original source and its translation are on file with the Indiana Health Law Review.).

97 Id. at art. 215. 
reward creates an obligation of result for the agent ${ }^{98}$ and is a voidable contract. Article 565 of the Civil Code provides that either party in a contract of reward [ju'alah] may withdraw because the contract is permissive. ${ }^{99}$ If the person paying the reward terminates the contract while the act is being carried out, the agent must still be compensated reasonably for the act. 100 This ensures that the organ donor may terminate the undertaking at any time, thereby safeguarding the donor's consent.

This is exactly the legal qualification of the Byelaw of 1997, where the State has offered a certain sum of money as a reward to whosoever may donate their kidney. 101 The protocols in place protect the consent of donors by ensuring that they may rescind their decision to donate at any time. The compensation for donation is provided to the donors only after the transplant takes place. Therefore, the official compensated scheme for human organ transplants only applies to live donors and is a reward for the act of donation, not the sale and purchase of kidneys.

\section{Ambiguous TRANSACTIONS AND ABSURD CONSEQUENCES}

A particular ambiguity exists with respect to the current agreements reached by individuals outside the official framework described above. As was noted, the compensation provided by the State has not been increased over the years and has lost any meaning as an incentive. The result is that notices are now illegally posted on websites or the walls and adjacent streets of transplant centers whereby offers are made to "purchase" kidneys of particular blood types needed by potential recipients. ${ }^{102}$ This raises an important question: if such transactions take place between private parties, what would be the legal qualification of the transaction?

This is further complicated by the numerous fatawa that have authorized the sale and purchase of organs. The lack of an express prohibition on the sale of human organs in Iranian

\footnotetext{
98 Id. at art. 567.

$99 \mathrm{Id}$. at art. 565.

100 Id.

101 Byelaw on Kidney Donors supra note 63.

102 Dehghan, supra note 10.
} 
law and the possibility of resorting to fatawa by virtue of Article 3 of the Civil Procedure Code in certain cases 103 further complicates the issue. The said article, with the intent to prevent a non liquet, provides:

Justices of the Courts [judges of the courts] shall adjudicate claims, issue judgments, and settle disputes based on law. If positive [posited] laws are incomprehensive or unspecific or contradictory or non-existent in the case in question, they shall issue their ruling of the case by reference to reputable Islamic sources or reputable fatawa and legal principles that don't contradict the criteria of Shari'a, and they may not refrain from hearing claims and issuing judgments due to the silence or deficiency or brevity or contradiction of the law, else they shall be held to be in denial of justice and convicted accordingly.

Note- If a judge is a mujtahid and considers the law to be in violation of Shari'a, the case shall be referred to another Chamber for adjudication. 104

Of course this provision in and of itself may not result in uniform jurisprudence on issues that are inadequately regulated. The Iranian judicial system is based on the French Civil Law system, and the sole authority capable of creating uniform judicial practice in Iran is the Supreme Court. Therefore, courts of first instance and of equal standing do not have to abide by each other's decisions. In view of the various approaches in the fatawa on human organ donation, particularly the legal qualification of such donations, it will ultimately fall on the Supreme Court to decide on divergent judgments from the lower courts on issues such as the sale and purchase of organs. However, the question remains that in view of the silence of the law, would a judge who is confronted by a claim of organ purchase with the intent to transplant, rule in favor of the "purchaser" and force the "seller" to undergo a transplant operation? Alternatively, would the court order compensation for breach of contract instead of specific performance? This is particularly important in that the majority of fatawa do not

103 Aini DADRASsir MADANI [Civil Procedure Code] Tehran 1379 [2000] art. 3 (Iran) (The original source and its translation are on file with the Indiana Health Law Review.).

104 Id. 
seem to have taken into account the wider policy implications of the possibility for the sale and purchase of organs.

The advisory opinions issued by the Legal Bureau of the Judiciary 105 (the Bureau) are also indicative of a legal conundrum on this question. The Bureau appears to be unable to decide on the legal nature of the donation of organs. In an advisory opinion ${ }^{106}$ issued in 2005 and citing the BDL, it has declared that the sale or donation of organs for transplants is permissible, but appears to be at a loss as to what consequences may arise if the heirs of a decedent who has "sold" or donated her organs reject the procurement procedure. ${ }^{107}$ The Bureau, somewhat befuddled, states that apart from filing a civil action against the heirs to fulfill the obligation of the decedent, no other recourse appears to be available. ${ }^{108}$ The Bureau has also used the term "sale" in another of its opinions, ${ }^{109}$ surprisingly by reference to the BDL, which makes no reference to the legal qualification of the transfer of cadaveric organs. It declares that the sale and purchase of human organs is illegal except in the framework of the BDL and its Byelaws. This position of the Bureau is particularly interesting in that it also contradicts many of the fatawa on the donation of cadaveric organs.

The Bureau appears to consider the BDL as an exception to a general prohibition of organ extractions and, in fact, uses the term "donation" of organs in other opinions and insists that the act of donation should not contravene human

105 This Bureau is part of Iran's judicial structure. Among other things, it is tasked with providing advisory opinions on judicial matters and publication of these opinions for reference by the courts. However, its opinions are not binding and even the website of the Bureau has a disclaimer to the effect that the advisory opinions do not necessarily reflect the official positions of the Judiciary. See Legal Bureau of the Judiciary, http://www.edarehoquqy.ir/ [http://perma.cc/8ZX8-QNQ3]. (The original source and its translation are on file with the Indiana Health Law Review.).

106 Opinion Number 7/7712, January 3, 2005, File No. 83-30-1770. (The original source and its translation are on file with the Indiana Health Law Review.).

107 Id.

108 Id. $\uparrow 2$.

109 Opinion Number 7/770, Apr. 29, 2009, File No. 88-30-47. (The original source and its translation are on file with the Indiana Health Law Review.). 
dignity, 110 and is mindful of humanitarian and ethical considerations. ${ }^{111}$ Another widely cited opinion of the Bureau that has also been referenced by the monthly publication Dadrasi, has stated that human organs cannot be sold because they are not property, but an individual may donate them to others when alive or after death and receive compensation. 112

In view of the foregoing and the fact that the Supreme Court has not yet issued a judgment on the matter, it is uncertain how the courts in Iran would handle a case of organ sale. On the one hand, the general freedom of contract and the silence of the law on the sale of human organs, coupled with the fatawa that are permissive of such sales, may be considered to provide license for the sale of human organs. If so, the courts would have to enforce an agreement for the sale, either issuing a judgment reminiscent of Shakespeare's Merchant of Venice to the effect that the seller should check into a transplant center and have his or her organ removed and surrendered to the purchaser, or ordering compensation for breach of contract.

This conclusion may also appear to be supported by reference to the provisions of the Iranian Civil Code on sales, which in Article 339 provides that a sale is concluded by offer and acceptance without requiring a written contract.113 The Code goes on to provide in Article 362 that upon such conclusion, the buyer becomes the owner of the object of sale and the seller is responsible for surrendering the object of sale to the buyer. ${ }^{114}$ Furthermore, contrary to a contract of

110 Opinion Number 7/4067, Oct. 2, 2010. (The original source and its translation are on file with the Indiana Health Law Review.).

111 Opinion Number 7/5077, Oct. 10, 2005, File No. 84-30-172. (The original source and its translation are on file with the Indiana Health Law Review.).

112 Markaze Tahghighate fiqhi-e Ghoveye Ghazaie [The fiqh Research Center of the Judiciary], Estefta'ate Fiqhi-Ghazaii (dar omoore hoghooghi) [Judicial/Islamic Opinions (on civil matters)], 43 Dadrasi Journal, 44, 45 (2004), (referencing Opinion Number 7/1558, Sept. 24, 1997). (The original source and its translation are on file with the Indiana Health Law Review.).

113 QANuni MADANi [Civil Code] Tehran 1314 [1935], art. 339 (Iran). (The original source and its translation are on file with the Indiana Health Law Review.).

114 Id. at art. 362 (Iran). 
reward, a contract of sale is not a voidable contract and failing an agreement by both parties to revoke, or in case the various reasons for termination under the Civil Code ${ }^{115}$ are not met or stipulated, including the right of termination without cause, 116 it appears that the Bureau is right in that the buyer may file a civil action for breach of contract.

This conclusion, however apart from being counterintuitive and contrary to the Iranian juris-culture, ${ }^{117}$ necessitates certain assumptions and entails particular consequences that are not justified under the Iranian legal system. Of particular importance here is the possibility of ownership of the human body in general or human organs in particular. The fatawa that are permissive of selling human organs are based on the premise that such organs are of value and may therefore be the subject of transactions; but, save for a few, they have not addressed the separate question of ownership of the human body or organs in this context.

The assumption of the possibility of owning a part of another human being, which would be the result of accepting human organ sales by virtue of Article 140 of the Civil Code $^{118}$ and relevant provisions cited above, would result in slavery or slavery-like practices which have been illegal in Iran by virtue of international treaties signed ${ }^{119}$ and ratified

115 Id. at arts. 396 et seq (Iran).

116 Id. at arts. 399-401 (Iran).

117 Apart from the ambivalence of the Bureau, the current practice of authorities such as public notaries, courts, and organ procurement centers does not seem to support this conclusion. A widely cited note by the Secretary of the Civil Laws Commission of the Supreme Council for Judicial Development, Dr. Ali Abbas Hayati, also rejects this conclusion. See Ali Abbas Hayati, Mabnaye Hoghooghie Ehda va Paivande A'zaye Badan [The Legal Basis of Donation and Transplant of Organs], 156 Farhango Pajouhesh 12 (2004) (Iran). (The original source and its translation are on file with the Indiana Health Law Review.).

118 Section 2 of this article stipulates that contracts and obligations are a cause of ownership, and one of the most prominent examples of transfer of ownership is the contract of sale, which as discussed above, is a cause of immediate transfer of ownership from seller to buyer under Iranian law. QANUNI MADANI [CIVIL CODE] Tehran 1314 [1935], art. 140 (Iran). (The original source and its translation are on file with the Indiana Health Law Review.).

119 Slavery Convention of 1926, art. 1, Sept. 25, 1926, 60 L.N.T.S. 253. Slavery is defined as "...the status or condition of a person over 
by Iran, ${ }^{120}$ and Iranian national legislation. ${ }^{121}$ The assumption of owning another human being's organ(s) would empower the purchaser to unlimited and unrestricted exploitation and use, and the establishment of a right of ownership and claim to a part of another person. ${ }^{122}$

The consequences of assuming ownership of the human body would also be absurd and would involve numerous questions too detailed and varied to cover in this paper. These include issues such as the possibility of transfer of ownership of the organ by the purchaser to another buyer, possibly for a profit; the matter of inheriting organs by heirs of the purchaser and devolution of ownership rights to third parties by reason of a decedent buyer's will and testament; and the possibility of a criminal charge for crime(s) committed against property, possibly by the organ donor. Taken together, these considerations make it extremely unlikely that a court would uphold a claim for compensation due to breach of contract, the subject of which is the sale of human organs.

On the possibility of requesting specific performance by the donor, it is worthy to note that lex specialis derogat legi generali: special laws will have precedence over general legislation where they exist. If in the unlikely scenario, even as a thought experiment, a court were to render a judgment in favor of a claimant and order the surrender of the organ

whom any or all of the powers attaching to the right of ownership are exercised."

120 Supplementary Convention on the Abolition of Slavery, the Slave Trade, and Institutions and Practices Similar to Slavery, art. 7, Sept. 7, 1956, 226 U.N.T.S. 3. Article 7(a) of this treaty provides: "Slavery" means, as defined in the Slavery Convention of 1926, the status or condition of a person over whom any or all of the powers attaching to the right of ownership are exercised, and "slave" means a person in such condition or status."

121 This national legislation includes the prohibition of slavery. Qanuni Man'e Kharido Forooshe Barde dar Khake Iran va Azadi Barde dar Moghe'e Vorood be Mamlekat [Prohibition of the Purchase and Sale of Slaves in Iranian Territory and Freedom of Slaves upon Entry to the Country], Tehran 1307 [1929], Iran. (The original source and its translation are on file with the Indiana Health Law Review.).

122 QANUNI MADANI [CIVIL CODE] Tehran 1314 [1935], art. 30 (Iran). (The original source and its translation are on file with the Indiana Health Law Review.). 
by the "seller," it is unimaginable how the operation would take place. Iranian criminal laws are replete with provisions on the inviolability of the human body, including post mortem. ${ }^{123}$ Particular medical law and regulations ${ }^{124}$ are also prohibitive of any surgical procedure without the written authorization of the patient, and the particular requirement for establishing the consent of organ donors for organ transplants procedures has already been covered. It is unimaginable that a transplant center would undertake a transplant operation without the consent of the donor and risk civil action and criminal charges.

In view of the above, it is safe to assume that should a case be brought to court requesting the enforcement of a "sale" of a particular organ, the court will either treat it as an agreement for donating an organ under a contract of reward (ju'alah) and respect the will and consent of the donor in revoking the agreement, or reject the submissions of the claimant as violating public order. ${ }^{125}$ Until such time that such cases are taken to court however, it will not be absolutely clear what direction the courts or the Supreme Court will take.

\section{CONCLUSION}

Any State that decides to provide some form of financial incentive for organ donation should also provide safeguards against the rather dramatic realization of the Shakespearean scene from the Merchant of Venice and fully protect the dignity and consent of donors. The Iranian model of organ transplantation appears to have been somewhat successful in preventing such an outcome. Contrary to popular belief that the Iranian model of organ donation is one of organ sales, by virtue of the particular legal concept of reward or

123 QAnuni Mojazate Eslami [Islamic Penal Code] Tehran 1370 [1991], art. 494 (Iran).

124 See Manshoore Hoghughe Bimar dar Iran [Charter on Patients' Rights in Iran] Tehran, 1388 [2009], art. 3 (Iran), available at mehr.tums.ac.ir/ShowLaw.aspx?LawID=46 [https://perma.cc/8FNHK5MU].

125 Aini Dadrassit Madani [Civil Procedure Code] Tehran 1379 [2000] art. 6 (Iran). (The original source and its translation are on file with the Indiana Health Law Review.). 
ju'alah under Iranian law that governs the act of donation and by the establishment of structural safeguards, Iran has managed to provide a compensated incentive to donors without objectifying them or their organs. The prohibition of transplant tourism, ensuring that donors receive free healthcare, provision of free psychological and vocational evaluations and consultations to donors further ensures their welfare. This particular legal regime of organ donations, coupled with the particular provisions of Iranian regulations on live and cadaveric donations, has managed to overcome the organ shortage in Iran and save thousands of lives.

However, much may be said of the fact that many live unrelated donors are undergoing transplant procedures for reason of economic hardship. Such financial distress is a major impediment to the equitable application of the principles of justice and autonomy to donors, but needs to be addressed in the wider context of socio-economic considerations of a nation's healthcare system. The fact of back-alley deals between donors and recipients in Iran is a major concern that needs immediate attention, possibly by adjusting the reward for organ donors to meet the true inflation rate in Iran and tightening the loopholes in current regulations, obviating the need and possibility for donors to conclude transactions with recipients outside the official transplant framework.

Despite these flaws and shortcomings, the fact is that the overall approach of the Iranian model may prove beneficial to reforming the current policy and regulations on human organ transplants in the United States and overcoming the organ shortage that is causing the death of thousands of patients on waiting lists every year. The notion of buying or selling human organs understandably causes pause for most people, if not outright aversion or disgust. However, rewarding the act of saving another person's life is a wellestablished and welcome approach. The question of compensating organ donors should not be addressed within a discourse of "purchase and sale of human organs," but of "rewarding the act of saving a fellow human being's life," even if such reward may include monetary compensation. 